DOI: https://doi.org/10.32838/2523-4803/70-6-20

УДК: 338.2

\title{
Ліснічук О.А.
}

кандидат економічних наук, доцент,

доцент кафедри фінансів імені Л.Л. Тарангул,

Університет державної фіскальної служби України

ORCID: https://orcid.org/0000-0002-2563-0717

Яроцик Т.Ю.

магістрант,

Навчально-науковий інститут фінансів, банківської справи

Університету державної фіскальної служби України

\section{Lisnichuk Oksana, Yaroshchuk Tetyana}

University of the State Fiscal Service of Ukraine

\section{АНАЛІЗ ПЕРЕВАГ ТА НЕДОЛІКІВ РОЗВИТКУ МАЛОГО БІЗНЕСУ В УКРАЇНІ}

\begin{abstract}
У статті проаналізовано статистичні показники малого бізнесу за період 2010-2019 рр., досліджено динаміку змін кількості суб 'єктів малого бізнесу України загалом, а також окремо кількість малих підприємств. Проведено аналіз кількості зайнятих прачівників на підприємстві, а також обсягів реалізованої продукиії. Розраховано частоту надходжень до державного та місиевого бюджетів від суб 'єктів малого бізнесу. 3 'ясовано головні особливості характерні для малого підприємництва. Досліджено основні показники, що вплинули на економічну ситуацію в краӥні та на бізнес загалом. Виявлені позитивні тендениії та недоліки функціонування малого бізнесу в Україні. Запропоновано напрями розв 'язання проблем, що залишили негативний відбиток на підприємствах. Визначено основні умови для розвитку малого бізнесу в країні.

Ключові слова: малий бізнес, мале підприємництво, суб'єкти малого бізнесу, фінансова криза.
\end{abstract}

Постановка проблеми. У високорозвинених країнах малий бізнес є невід'ємною частиною економічної системи та основним суб'єктом національної економіки. Процвітання малого підприємництва в Україні $\epsilon$ значущою передумовою для вирішення соціальних $\mathrm{i}$ фінансових проблем окремих регіонів і країни загалом, залучення до бізнесу чималої частини населення, підвищення зайнятості населення, створення конкурентного середовища та переходу до інноваційного типу фінансового розвитку.

В умовах фінансової мінливості малий бізнес має декілька переваг, що свідчать про актуальність досліджуваної теми. Це незначний розмір початкових (стартових) інвестицій, висока швидкість обороту ресурсів та гнучкість діяльності. Проте мінливість зовнішнього середовища, зокрема відсутність підтримки з боку держави, можуть гальмувати розвиток малого підприємництва, негативно впливаючи на зацікавленість населення у початку та продовженні такої діяльності.

Аналіз останніх досліджень і публікацій, виділення не вирішених раніше частин загальної проблеми. Дослідженню проблем розвитку малого бізнесу в Україні та його впливу на національну економіку присвячена велика кількість наукових робіт. Тотожною $є$ позиція вчених стосовно значущості малого бізнесу для подолання кризових явищ в економіці і подаль- шого іiї зростання, а також відставання нашої країни від провідних країн світу за показниками розвитку цієї сфери бізнесу.

Дослідженням цієї проблематики займалися такі вчені, як: Л.І. Пронкіна, І.Б. Гобир, Н.А. Шикіна, О.А., Ліснічук, Л.І. Воротіна, С.Л. Азізова, А.О. Корнецький, В.Ю. Медяник, Д.З. Пиріг, С.К. Реверчук та інші. Чухно I.А. стверджує, що територіальні громади та органи місцевої влади мають бути більш зацікавленими в забезпеченні розвитку малого бізнесу. А Н.В. Гришина наголошує на тому, що одним із напрямів ефективного використання потенціалу малого підприємництва може стати удосконалення відносин малого бізнесу 3 великими підприємствами.

Мета статті. Основною метою роботи є виявлення та аналіз головних переваг і недоліків розвитку малого бізнесу в Україні, визначення основних умов для розвитку малого бізнесу. За різноманітної кількості поглядів із вивчення малого підприємницького сектору економіки проблеми функціонування таких підприємств та їхній розвиток ще досі $є$ не повністю дослідженими, що залишає питання актуальним щодо продовження поглибленого дослідження зазначеної сфери.

Виклад основного матеріалу. Завдяки малому бізнесу реалізуються великі економічні програми, наповнюється державний бюджет і всі соціальні фонди, 
ринок насичується товарами й послугами, створюються нові робочі місця. Роль малого бізнесу у вітчизняній економіці так само важлива, як і в промислово розвинених країнах, де на його частку припадає до 80 відсотків ВНП.

В Україні спостерігається постійне зростання підприємців. Відповідно до даних Державної фіскальної служби України, на початок 2020 року кількість зареєстрованих фізичних осіб - підприємців в Україні становила 1889,9 тис. осіб, що на 18,5 тис. більше, ніж на початок 2019 року. Зокрема, станом на 2019 рік загальна кількість зареєстрованих суб'єктів господарювання 3 урахуванням банків в Україні становить 1941701 од., 3 них 1561028 од. - фізичні особи - підприємці (рис. 1).

Суб'єкти малого бізнесу займають домінуючу позицію в економіці країни. Їхня кількість стабільно сягає 99\% від загальної кількості суб'єктів підприємництва, що свідчить про значущість малого бізнесу для національної економіки. Спостерігаємо, що в період 3 2010 по 2019 рік кількість суб'єктів господарювання постійно змінюється, це пов'язано з факторами впливу на мікро- та макрорівнях. Так, у період з 2010 по 2012 рік кількість підприємців скорочується на 26,7\% через кризові процеси, які послабили позиції України у світовій економіці, зменшення кількості суб'єктів малого бізнесу в період з 2015 по 2018 рік на 6,82\% сталося внаслідок недофінансування державних програм фінансової підтримки малого бізнесу.

Спостерігаємо, що кількість суб'єктів підприємництва в період з 2010 по 2019 рік постійно коливалася. Так, з 2010 по 2012 рік їх кількість знизилася на 13193 одиниць, ці зміни відбулися внаслідок кризових явищ в економіці України. А в період з 2012 по 2013 рік обсяг підприємств різко зріс на 29761 одиниць, що свідчить про покращення економічного середовища для бізнесу. Далі показники пішли на спад за рахунок ще однієї фінансової кризи в країні та війни на Сході, проте ненадовго. Зниження в 2017 р. єдиного соціального внеску до 22\% дало можливість підприємствам не тільки легалізувати найману працю, але й спрямувати зекономлені кошти на саморозвиток, і в результаті в 2017 році кількість малих підприємств зросла

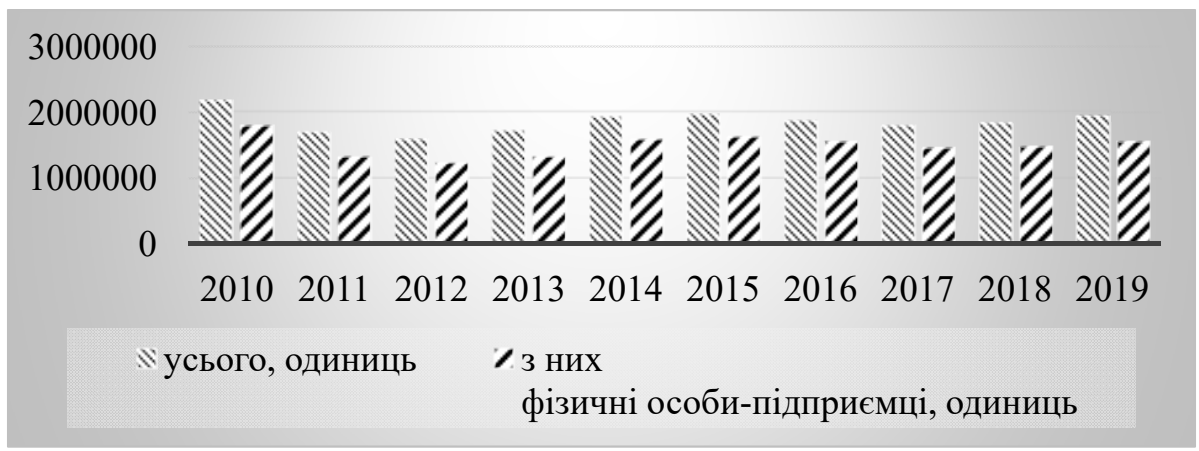

Рис. 1. Загальна кількість заресстрованих суб'сктів малого бізнесу

Джерело: складено автором на основі [1]

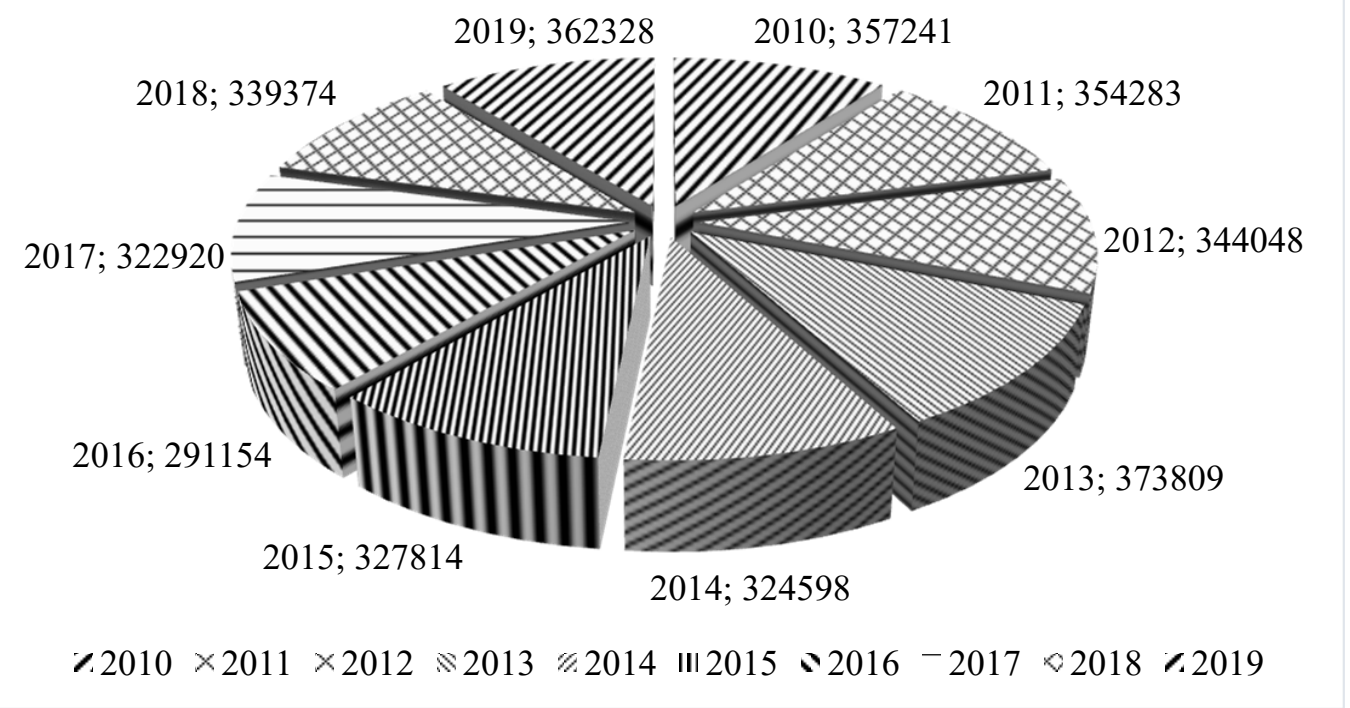

Рис. 2. Кількість малих підприємств із 2010 по 2019 рік

Джерело: складено автором на основі [2] 
на 31766 одиниць порівняно з 2016 р., а в 2019 році майже досягла рівня 2013 року, що свідчить про покращення економічної ситуації в Україні.

Розвиток малого бізнесу вагомо впливає на зайнятість населення. Малий бізнес забезпечує більшу зайнятість населення на нових робочих місцях, ніж великі підприємства, що значно знижує напруженість у суспільстві, пов'язану з безробіттям [4]. Відповідно до даних Державної служби статистики України спостерігаємо, що кількість зайнятих осіб на великих підприємствах скорочується в період 2013-2015 рр. на 3,2\%, а малого підприємництва - на 0,3\% внаслідок воєнного конфлікту на Сході України та масового відтоку працездатних осіб за кордон. А у 2016 році кількість зайнятих осіб як на великих, так і на малих підприємствах досягає однакового значення $-27,4 \%$ зайнятих осіб. Саме в період із 2016 по 2017 рік спостерігається позитивна динаміка росту зайнятості населення в Україні.

Якщо брати до уваги світовий досвід, то малий бізнес $є$ значною противагою великому бізнесу, через те що він займає ті сфери виробництва товарів і надання послуг, що, як правило, не викликають зацікавленості у представників великого бізнесу, проте користуються попитом у населення; а з іншого боку, малий бізнес дає можливість підтримувати соціальну справедливість у суспільстві, оскільки він зорієнтований на пересічних громадян із середніми та малими матеріальними статками [5].

Важливим показником діяльності суб'єктів малого бізнесу є обсяг реалізованої продукції та його частка в загальному обсязі продажів по всій Україні. Проаналізувавши дані обсягів реалізованої продукції малими підприємствами з 2010 по 2019 рік, можна сказати, що цей показник $є$ досить таки позитивним і вражаючим. За цим показником малий бізнес вказує на стійку позитивну динаміку змін із кожним роком.
За підсумками 2019 року, обсяг реалізованої продукції (товарів чи послуг) суб’єктів малого бізнесу порівняно з 2018 роком зріс на 73 млн 725446 тис. грн., тобто на $13 \%$. Його частка становила $22 \%$ від загальної суми експортованої продукції по Україні загалом, тобто третина всього обсягу реалізованої продукції припадає саме на малий бізнес, що свідчить про його значущість у фінансовій системі нашої країни.

Не слід забувати, що вагомий внесок у соціальноекономічний розвиток країни вносять як великі товариства, так і малі підприємці, які виділяють кошти на розвиток інфраструктури населених пунктів та покращення медичних, освітніх та культурних послуг, що надають можливість підвищити якість життя населення [7].

Надходження грошових коштів до бюджетів усіх рівнів від суб'єктів малого бізнесу на 2020 рік становили 46,6 млн грн.: від малих підприємств - 36,9 млн грн., від фізичних осіб-підприємців - 9,7 млн грн. Частка податкових надходжень від малого підприємництва становить $25,6 \%$.

Майбутній розвиток підприємництва та зростання на цій основі надходжень до державної скарбниці дає змогу вирішувати низку найактуальніших соціальноекономічних проблем, прогнозує зміцнення економіки, надає ӥй гнучкості, створює нові робочі місця. Підприємці нерідко беруть участь у фінансуванні місцевих програм, будучи зацікавленими у фінансовому розвитку території, на якій вони знаходяться.

Досліджуючи функціонування, особливості розвитку та деякі інші сторони малого бізнесу, слід звернути увагу та визначити низку переваг цього виду економічної діяльності [3]. Основні з них:

- цей сегмент ринку є гнучким та динамічним, здатним швидко адаптуватися до мінливого середовища;

- доступ до малого бізнесу та входження в цей сектор економіки є відкритим для громадян України;

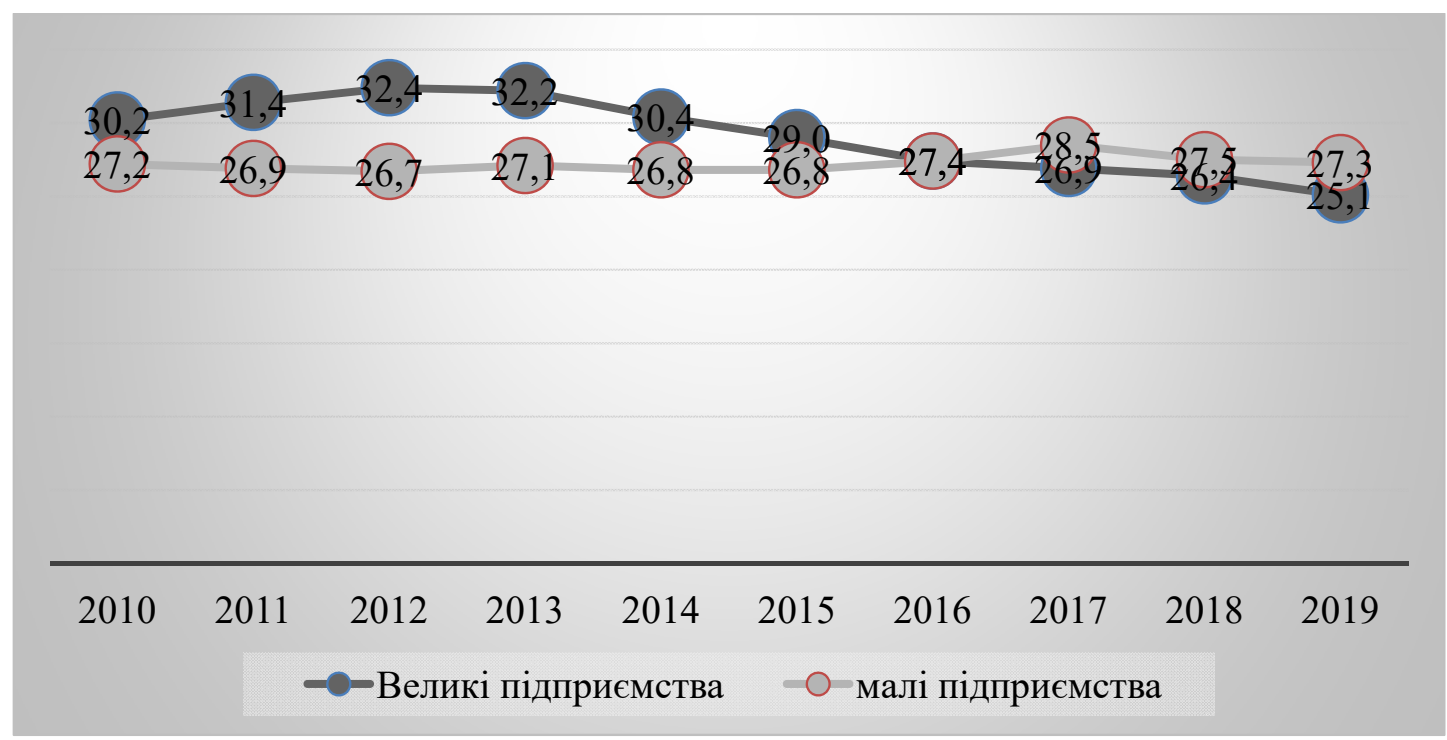

Рис. 3. Кількість зайнятих осіб на підприємствах із 2010 по 2019 рік, \%

Джерело: складено автором на основі [2] 
- завдяки розвитку малого підприємництва створюються нові робочі місця та у зв'язку з цим вирішується низка соціальних питань;

- сприятливі умови ведення малого бізнесу підвищують мотивацію до праці та розвитку інноваційного потенціалу підприємств.

Беручи до уваги позитивні показники діяльності малого бізнесу, не слід забувати, що йому нелегко вижити в економічних умовах нашої країни. Багато підприємців скаржаться на несприятливі умови для ведення бізнесу в Україні.
Проаналізувавши економічні показники, спостерігаємо, що у 2017 році на бізнес-середовище найбільший вплив мав рівень інфляції, який становив 56\%, що значно погіршив клімат в економічному середовищі нашої країни. У 2019 році рівень інфляції значно знизився, що зменшило вплив на бізнес, проте високий рівень корупції та рівень податкового навантаження підвищили його.

Окрім переваг малого підприємництва [5], слід вказати і на недоліки, притаманні цьому виду економічної діяльності. Наприклад:

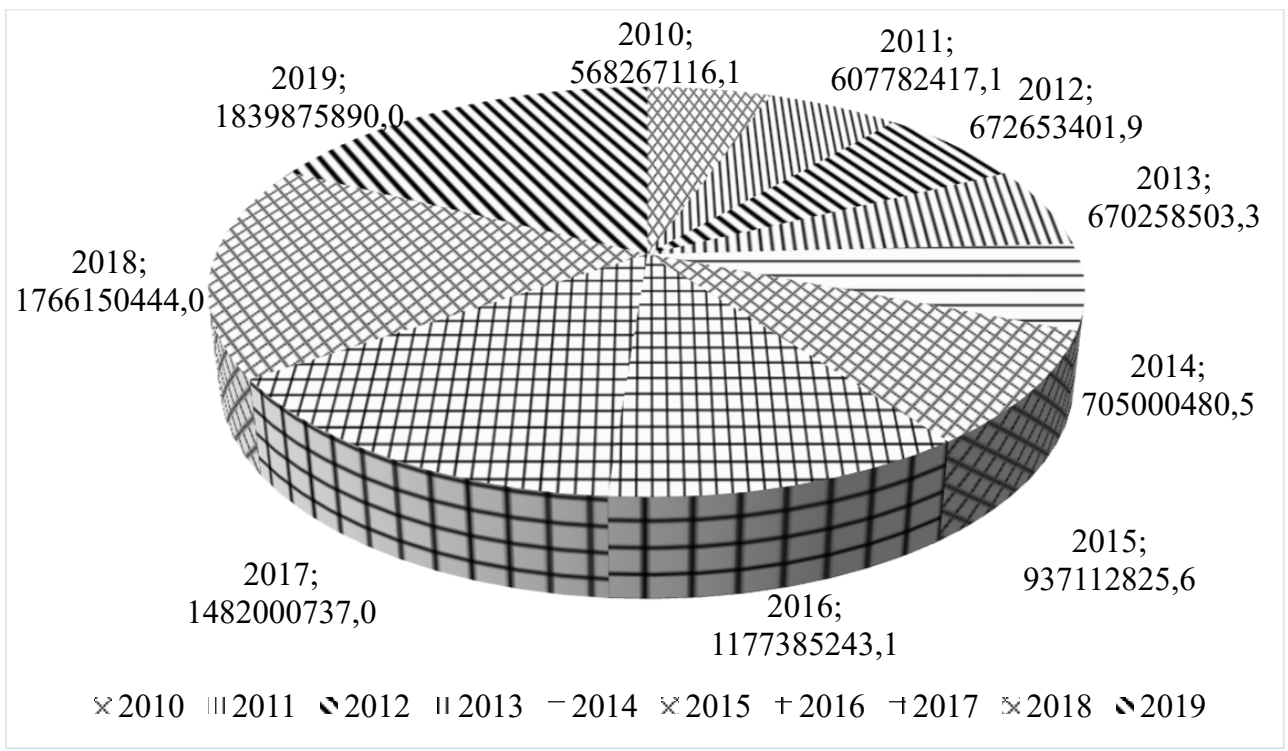

Рис. 4. Обсяг реалізованої продукції малим бізнесом за 2010-2019 рр.

Джерело: складено автором на основі [2]

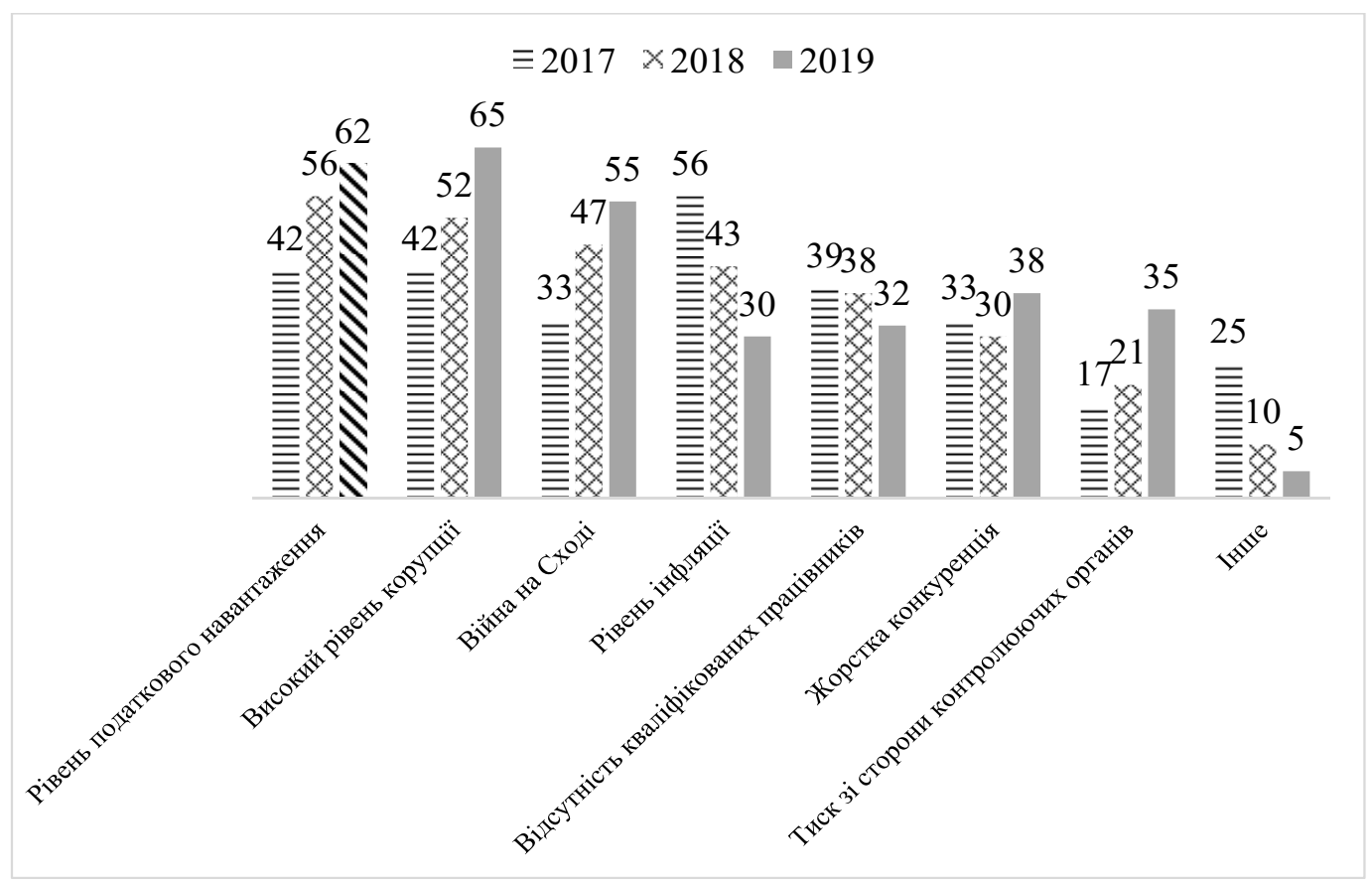

Рис. 5. Показники впливу на економічну ситуацію 2017-2020 рр.

Джерело: складено автором на основі [6] 
- нестача фінансових коштів, що у результаті спричиняє використання лише власного капіталу чи потреби запозичення фінансових ресурсів, що ускладнено кризовою економічною ситуацією та відсутністю спеціально продуманої кредитної політики;

- недостатній рівень необхідного сировинного та технічного оснащення порівняно 3 великими підприємствами;

- висока залежність діяльності підприємства від монопольного замовника, що обмежує здатність до тактичного ходу;

- високий рівень впливу ринкової кон'юнктури;

- досить низька частка продукції виробництва на товарному ринку;

- високий рівень ризику банкрутства;

- відчутний вплив зовнішніх економіко-кризових факторів порівняно з представниками середнього та великого бізнесу (інфляція, економічний спад, влив монополії, нечесна конкуренція тощо).

Згідно зі Стратегією розвитку малого та середнього підприємництва в Україні запропоновано такі напрями [6] розв'язання вищезазначених недоліків розвитку малого бізнесу в Україні:

- створення задовільного середовища для розквіту малого бізнесу за допомогою покращення інформаційного забезпечення підприємств та залучення допомоги з боку державних органів влади;

- створення умов для зберігання депозитних коштів банками, допомога у кредитуванні підприємств та розширення кредитних послуг, надання послуг із факторингу та лізингу, щоб знизити дефіцит фінансування малого бізнесу;

- надання можливості роботодавцям підвищувати фінансову грамотність своїх працівників та сприяти їх розвитку;
- покращення конкурентноздатності малого підприємства та підвищення його інноваційного потенціалу на основі розширення діапазону послуг та якості їх надання.

Враховуючи основні переваги та недоліки малого бізнесу, необхідно визначити умови для його розвитку та процвітання в нашій країні. До таких умов віднесемо [7] впорядкування спрощеної системи оподаткування малого підприємництва шляхом звуження переліку видів економічної діяльності; сприяння кращому розвитку інноваційного бізнесу; формування сучасної фінансової інфраструктури підтримки підприємництва в Україні за зразком високорозвинених європейських країн та надання більшої частки прямої державної фінансової підтримки малого бізнесу.

Висновки. Спостерігаємо, що 3 кожним роком суб'єктів малого бізнесу на ринку стає все більше, що спричиняє ріст підприємств. У результаті збільшення кількості підприємств зростає кількість зайнятих працівників, тобто підвищується рівень зайнятості населення. Майже третина всього обсягу реалізованої продукції припадає саме на малий бізнес, що свідчить про його значущість у фінансовій системі нашої країни. Проте протягом декількох років видно, що малому бізнесу стає все важче працювати. Підприємці не задоволені наявним податковим навантаженням, високим рівнем корупції, незахищеністю з боку держави та судової влади, неможливістю залучення додаткових фінансових ресурсів, що спричиняє зниження мотивації у веденні такого роду діяльності.

Підсумовуючи вищесказане, необхідно зазначити, що одним із ключових напрямів розвитку економіки країни є розвиток малого бізнесу. Ця форма підприємництва дасть змогу досить швидкими темпами підняти рівень національної економіки країни, збільшити кількість робочих місць, підняти рівень соціального життя населення та вивести країну на новий світовий рівень.

\section{Список літеартури:}

1. Державна фіскальна служба України. URL: https://tax.gov.ua (дата звернення: 01.10.2020).

2. Державна служба статистики України. URL: http://www.ukrstat.gov.ua (дата звернення: 01.09.2020).

3. Гобир І.Б., Мельник М.I. Державна підтримка розвитку малого підприємництва в Україні в кризових умовах. Агросвіт. 2017. № 10. С. 65-69.

4. Чухно I.А. Малий бізнес та його роль в контексті територіального розвитку. Публічне управління XXI століття: світові практики та національні перспективи : зб. тез XVIII Міжнар. наук. конгресу, м. Харків, 26 квітня 2018 р. Харків : РІ НАДУ «Магістр», 2018. С. 437-440.

5. Корнецький А.О. Формування та реалізація регіональної політики розвитку малого підприємництва : монографія. Дніпро : УМСФ, 2016. 140 с.

6. Ліснічук О.А., Матвійчук В.В. Шляхи забезпечення ефективного функціонування малого підприємництва в Україні. Збірник наукових праць Університету державної фіскальної служби України : електронне наукове видання. 2019. № 2. C. 173-188.

7. Пиріг Д.З. Досвід розвитку управління інноваційною діяльністю малих підприємств у зарубіжних країнах. Актуальні проблеми економіки. 2018. № 3 (105). С. 163-170.

\section{References:}

1. Derzhavna fiskalna sluzhba Ukrainy. Available at: https://tax.gov.ua (accessed 01 October 2020).

2. Derzhavna sluzhba statystyky Ukrainy. Available at: http://www.ukrstat.gov.ua (accessed 01 October 2020).

3. Hobyr I.B., Melnyk M.I. (2017) Derzhavna pidtrymka rozvytku maloho pidpryiemnytstva v Ukraini v kryzovykh umovakh [State support of development of small enterprise is in Ukraine in crisis terms]. Agroworld, no. 10. pp. 65-69. 
4. Chukhno I.A. (2018) Malyi biznes ta yoho rol v konteksti terytorialnoho rozvytku [Small business and its role in the context of territorial development]. Proceeding of the Publichne upravlinnia KhKhI stolittia: svitovi praktyky ta natsionalni perspektyvy : zb. tez XVIII Mizhnar. nauk. konhresu (Kharkiv, April 26, 2018), Kharkiv: RI NADU «Mahistr», pp. 437-440.

5. Kornetskyi A.O. (2016) Formuvannia ta realizatsiia rehionalnoi polityky rozvytku maloho pidpryiemnytstva [Formation and implementation of regional policy for small business development]. Dnipro: UMSF, $140 \mathrm{p}$.

6. Lisnichuk O.A., Matviichuk V.V. (2019) Shliakhy zabezpechennia efektyvnoho funktsionuvannia maloho pidpryiemnytstva v Ukraini [Ways to ensure the effective functioning of small business in Ukraine]. Zbirnyk naukovykh prats Universytetu derzhavnoi fiskalnoi sluzhby Ukrainy [Collection of scientific works of the University of the State Fiscal Service of Ukraine] (electronic journal), no. 2, pp. 173-188. Available at: http://ir.nusta.edu.ua/jspui/bitstream/doc/4116/1/2938_ IR.pdf (accessed 05 October 2020).

7. Pyrih D.Z. (2018) Dosvid rozvytku upravlinnia innovatsiinoiu diialnistiu malykh pidpryiemstv u zarubizhnykh krainakh [Experience in the development of innovation management of small businesses in foreign countries]. Current economic problems, vol. 3, no. 105, pp. 163-170.

\section{АНАЛИЗ ПРЕИМУЩЕСТВ И НЕДОСТАТКОВ РАЗВИТИЯ МАЛОГО БИЗНЕСА В УКРАИНЕ}

В статье проанализированы статистические показатели малого бизнеса за период 2010-2019 г2., исследована динамика изменений количества субъектов малого бизнеса Украины в иеелом, а также отдельно количество мальх предприятий. Проведен анализ количества занятых работников на предприятии, а также объемов реализованной продукиии. Рассчитана частота поступлений в государственный и местный бюджеты от субъектов малого бизнеса. Выяснены главные особенности, характерные для малого предпринимательства. Исследованы главные показатели, которые повлияли на экономическую ситуацию в стране и на бизнес в изелом. Выявлены положительные тенденции и недостатки функционирования малого бизнеса в Украине. Предложены направления решения проблем, которые оставили негативный отпечаток на предприятиях. Определены основные условия для развития малого бизнеса в стране.

Ключевые слова: мальй бизнес, малое предпринимательство, субъекты малого бизнеса, финансовый кризис.

\section{AN ANALYSIS OF ADVANTAGES AND LACKS OF DEVELOPMENT OF SMALL BUSINESS IS IN UKRAINE}

In the article the statistical indexes of small business are analysed for period 2010-2019, the dynamics of changes of amount of subjects of small business of Ukraine is investigational on the whole, and also separately amount of small enterprises. The analysis of amount of the concerned workers is conducted on an enterprise, and also volumes of the realized products. The frequent is expected receivabless to the state and local budgets from the subjects of small business. Main features are found out characteristic for a small enterprise. Main indexes that influenced on an economic situation in a country and on business on the whole are investigational. The educed positive tendencies and lacks of functioning of small business are in Ukraine. Directions of decision of problems that left a negative imprint on enterprises are offered. Basic terms are certain for development of small business in a country. As a result of increase of enterprises - the amount of the concerned workers grows, id est the level of employment of population rises. Almost one third of all volume of the realized products is exactly on small business that testifies to his meaningfulness in the financial system of our country. However during a few years, evidently, that becomes small business all heavier to work. Businessmen are not content with the present tax loading, high level of corruption, unprotectedness from the side of the state and department judicial, impossibility of bringing in of additional financial resources, that causes the decline of motivation in slave such to activity. Having regard to positive performance of small business indicators, it does not follow to forget that it not easily him to survive in the economic terms of our country. Many businessmen grumble about unfavorable terms for doing business in Ukraine. It is educed that one of key trends of development of economy of country there is development of small business. This form of enterprise will allow rapid enough rates to heave up the level of national economy of country, increase a working seating capacity, heave up the standard of the social living of population and show out a country on a new world level.

Key words: small business, small enterprise, subjects of small business, fi-nancial crisis. 